\title{
Determination of antineoplastic activity of rohituka, aphanamixis polystachya (wall) rn parker in hela cells: correlation with clonogenicity and dna damage
}

\begin{abstract}
The antineoplastic activity of chloroform stem bark extract of rohituka, Aphanamixis polystachya (APE) used traditionally to treat spleen and liver tumors was evaluated in cultured HeLa cells by clonogenic and micronucleus assays. Treatment of HeLa cells with $0,5,10,25,50,75$ or $100 \mu \mathrm{g} / \mathrm{ml}$ APE for different times caused a concentrationdependent reduction in the cell survival up to $6 \mathrm{~h}$ post-treatment $(\mathrm{p}<0.005)$ followed by a non-significant decline in the cells treated with APE for $24 \mathrm{~h}$. Therefore, $6 \mathrm{~h}$ treatment time was considered as an optimum time for APE exposure and further studies were carried out using this treatment time. Exposure of HeLa cells to different concentrations of APE resulted in a concentration-dependent decline in the cell viability and $100 \mu \mathrm{g} / \mathrm{ml}$ APE resulted in $72 \%$ cell death when compared with the non-drug treated control group. These results were further confirmed by clonogenic assay where, APE treatment caused a concentration-dependent decline in the clonogenicity of HeLa cells, and the surviving fraction of cells was reduced to 0.22 after treatment with $100 \mu \mathrm{g} / \mathrm{ml}$ APE, the highest concentration screened. The inhibitory concentration $\left(\mathrm{IC}_{50}\right)$ of APE was found to be $25 \mu \mathrm{g} /$ $\mathrm{ml}$. The APE-induced DNA damage was estimated by micronucleus assay, where the treatment of HeLa cells with various concentrations of APE resulted in a concentrationdependent rise in the frequency of micronuclei in binucleate HeLa cells (MNBNCs) at 20,30 , and $40 \mathrm{~h}$ post-treatment. This increase in MNBNCs was significantly higher than the baseline frequency of MNBNCs. APE treatment also increased the frequency of HeLa cells bearing more than one micronucleus $(\mathrm{MN})$ indicating higher degree of DNA damage. The frequency of MNBNC increased with scoring time and a maximum elevation in the MNBNC frequency was observed at $30 \mathrm{~h}$ post-treatment. The MNBNC induction and clonogenicity of HeLa cells was inversely related indicating that increased MNBNC formation resulted in a corresponding reduction in the cell survival. The cell proliferation indices (PI) declined with increasing concentration of APE that increased with screening time. Our study demonstrates that APE is able to kill HeLa cells effectively and this cell killing effect of APE may be due its ability to induce DNA damage.
\end{abstract}

Keywords: hela cells, aphanamixis polystachya, cell survival, micronuclei, proliferation
Volume 3 Issue 4 - 2016

\author{
Ganesh Chandra Jagetia, VA Venkatesha \\ Department of Zoology, Mizoram University, India
}

Correspondence: Ganesh Chandra Jagetia, Professor Department of Zoology, Mizoram University, Tanhril,Aizawl-796 004, Mizoram, India, Tel 0I I-389-2330724, Email gc.jagetia@gmail.com

Received: October 10,2015 | Published: April 19, 2016
Abbreviations: APE, aphanamixis polystachya extract; $\mathrm{MN}$, micronuclei; SF, surviving fraction; MEM, minimum essential medium; DOX, doxorubicin; HeLa S3, human cervical carcinoma

\section{Introduction}

Though many of the presently used anticancer drugs are originated or derived from plants, an attempt to the isolation and clinical usage of single compound has caused severe adverse side effects like, myelosuppression, alopecia, nausea, gastrointestinal, reproductive and nephrotoxicity. In addition, most of the modern chemotherapeutic agents have been reported to induce secondary malignancies due to their carcinogenic potential in patients receiving therapy. ${ }^{1}$ This necessitates a continued search for newer novel natural products and/ or their semisynthetic analogs that may be useful as potential cancer chemotherapeutic drugs in the hope that it will be possible to encounter an agent/s that will be highly effective in treating neoplastic disorders without any side effect or minimum side effects when compared to the synthetic drug/s. ${ }^{2}$

Production of DNA damage is the basis of cancer treatments such as chemo- and radiotherapy. These treatments induce mitotic catastrophe, a form of cell death resulting from abnormal mitosis leading to the formation of interphase cells with multiple micronuclei.
Since majority of single compounds have cytotoxic and/or DNA damaging action, one of the preliminary investigation of medicinal plant screening is to examine the effect of fractionated components on the cell proliferation as well as on the DNA of cultured neoplastic cell lines. Micronucleus assay gives indirect indication of DNA damage in the cells exposed to different cytotoxic or DNA damaging agents, since micronuclei $(\mathrm{MN})$ arise from acentric fragments or whole chromosomes that lag behind during cell division. ${ }^{3,4}$ Formation of micronuclei indicates spontaneous elimination or loss of amplified sequences by tumor cells. ${ }^{5}$ Exposure of SCCVII murine carcinoma cells to chemotherapeutic drugs including cisplatin, carboplatin, etoposide, vincristine or 5-fluorouracil elevated the frequency of micronucleated binucleate cells. ${ }^{6}$ Cisplatin has also been reported to induce micronuclei in 9L tumor cells. ${ }^{7}$ Similarly, adriamycin, acyclovir or methanolic extract of Tinospora cordifolia were reported to induce micronuclei in HeLa and V79; cells. ${ }^{8-11}$ The use of natural products, especially plants may be beneficial in cancer treatment as more than $80 \%$ of the world population still depend on plants and natural products for healthcare. ${ }^{12,13}$ Moreover, the biologic origin of plants also make them more attractive as medicines for use in humans as this will have less toxic implications and acceptability in patients will also not pose any problem. ${ }^{14,15}$ 
Aphanamixis polystachya Wall Parker (Amoora rohituka (Roxb.) Wight \& Arn) or rohituka is distributed throughout India in evergreen forests and is a member of the family Meliaceae. The stem bark and seeds of this plant have been reported to be useful in splenomegaly, liver disorders, and treatment of tumors. ${ }^{16}$ The stem bark has been found to be useful in certain tumors including liver and spleen. ${ }^{17,18}$ The alcoholic extract of the stem bark has been reported to show anticancer activity against Friend's leukemia and Ehrlich ascites carcinoma in mice. ${ }^{15,19,20}$ The ethyl acetate fraction of rohituka has been found to protect against the radiation-induced chromosome damage. ${ }^{21}$ Certain alkaloids like, amoorastatin and 12-hydroxyamoorastatin, present in the stem bark extract of rohituka have been reported to exhibit cytotoxic and growth inhibitory activities in murine P388 lymphocytic leukaemia cells. ${ }^{22}$ Rohituka has been reported to contain certain alkaloids and limonoids. ${ }^{23,24}$ Limonoids have been reported to possess anticancer activity in various human cancer cell lines. ${ }^{25}$ Most of the limonoids are structurally highly complex and they would never have emerged from a synthetic program alone or from a combinatorial approach to new drug discovery. ${ }^{2,26}$ Therefore it is essential to screen newer natural products for the presence of antineoplastic activity. Presence of several medicinal properties in Aphanamixis polystachya and its common usage in the Ayurvedic medicine stimulated us to screen the antineoplastic activity of the chloroform fraction of the stem bark of Aphanamixis polystachya in the cultured HeLa cells in vitro.

\section{Materials and methods}

\section{Chemicals}

Eagle's minimum essential medium (MEM), fetal bovine serum, L-glutamine and cytochalasin-B were purchased from Sigma Chemical Co., (St. Louis, MO, USA). Doxorubicin (DOX) was obtained as a gift from Dabur Pharmaceuticals-Oncology division, New Delhi, India, whereas all other routine chemicals were procured from Ranbaxy Fine Chemicals, Mumbai, India.

\section{Cell line and culture}

HeLa S3 (human cervical carcinoma) cells, having a doubling time of $20 \pm 2 \mathrm{~h}$, procured from National Centre for Cell Science, Pune, India, was used throughout the study. The cells were routinely grown in $25 \mathrm{~cm}^{2}$ culture flasks (Techno Plastic Products, Trasadingën, Switzerland) with loosened caps containing Eagle's minimum essential medium (MEM) supplemented with $10 \%$ fetal bovine serum, $1 \% \mathrm{~L}$-glutamine and $50 \mu \mathrm{g} / \mathrm{ml}$ gentamicin sulfate at $37^{\circ} \mathrm{C}$ in an atmosphere of $5 \% \mathrm{CO}_{2}$ in humidified air in a $\mathrm{CO}_{2}$ incubator (NuAir, Plymouth, USA).

\section{Preparation of the extract}

Aphanamixis polystachya (Wall) RN Parker or Amoora rohituka (Roxb) Wight \& Arn (family-Meliaceae) or rohituka was identified by Dr. GK Bhat (a well known taxonomist) Department of Botany, Poorna Pragna College, Udupi, India and the herbarium specimen (RB-AP01) is stored with us. The bark of the tree was carefully peeled off, shade-dried, and coarsely powdered in a ball mill. The powdered bark was successively extracted with petroleum ether and chloroform in a Soxhlet apparatus for thirty cycles. The chloroform was allowed to evaporate at room temperature and the viscous extract was freeze-dried so as to obtain a fine powder of the extract. Henceforth, the chloroform stem extract of Aphanamixis polystachya will be called as APE.

\section{Preparation of APE solution}

APE was dissolved in DMSO immediately before use at a concentration of $25 \mathrm{mg} / \mathrm{ml}$ and diluted with MEM as required.

\section{Experimental}

A fixed number $\left(5 \times 10^{5}\right)$ of exponentially growing HeLa cells were seeded into several culture flasks (Techno Plastic Products, Trasadingën, Switzerland) and were allowed to attach for $48 \mathrm{~h}$. The cell cultures were divided into the following groups:

MEM group: The cells of this group were treated with $4 \mu 1 / \mathrm{ml}$ DMSO.

APE gorup: This group of cells was treated with $0,5,10,25,50,75$ or $100 \mu \mathrm{g} / \mathrm{ml}$ APE for $1,2,4,6,8,12,16$ or $24 \mathrm{~h}$.

DOX group: The cells of this group were exposed to $0,2,4,6,8,10$ or $12 \mu \mathrm{g} / \mathrm{ml}$ doxorubicin (positive control).

The following studies were carried out to ascertain the antineoplastic activity of rohituka in cultured Hela cells.

\section{Evaluation of optimum treatment time}

The optimum treatment duration for APE in HeLa cells was determined by estimating cell viability. ${ }^{26}$ The results obtained by this assay were further confirmed by clonogenic assay. ${ }^{27}$

\section{Pratt and Willis test}

A separate experiment was conducted to determine the optimum APE exposure time, where grouping and other conditions were similar to that described in the experimental section. Briefly, $5 \mathrm{x}$ $10 \mathrm{M}^{4} \log$ phase cells were seeded into $35 \mathrm{~cm}^{2}$ culture dishes (Cellstar, Greiner, Germany) in triplicate for each drug concentration. $24 \mathrm{~h}$ after initiation of the cultures the cells were treated with $0,5,10,25,50$, 75 or $100 \mu \mathrm{g} / \mathrm{ml}$ APE or $0,2,4,6,8,10$ or $12 \mu \mathrm{g} / \mathrm{ml}$ doxorubicin for 1 , $2,4,6,8,12,16$ or $24 \mathrm{~h}$. After the elapse of stipulated time, the drugcontaining medium was replaced with the fresh drug-free medium and the cells were left undisturbed in a $\mathrm{CO}_{2}$ incubator at $37^{\circ} \mathrm{C}$. The whole experiment was terminated after $72 \mathrm{~h}$ of initiation and the cells were dislodged by trypsin-EDTA treatment. The viability of cells was determined by trypan blue dye exclusion test using a hemocytometer (AO, American Optical Co., Cambridge, USA) under an inverted microscope (Ernst Leitz, Wetzlar GmbH, Wetzlar, Germany).

\section{Clonogenic assay}

The clonogenic potential of HeLa cells after APE treatment was evaluated by the method of Puck \& Marcus ${ }^{27}$ by conducting a separate experiment. The optimum APE treatment duration was determined by dividing the cells into two groups as described in the experimental section except, that 200-300 exponentially growing cells were plated on to several individual culture dishes (Cellstar, Greiner, Germany) containing $5 \mathrm{ml}$ drug free medium in triplicate for each drug concentration for each group. The cells were allowed to grow for $24 \mathrm{~h}$ and the cells of all groups were treated with various concentrations of APE or doxorubicin for $1,2,4,6,8,12,16$ or $24 \mathrm{~h}$ as indicated in the earlier section. The drug-containing media was replaced with APE free medium after the elapse of stipulated time. The cells were incubated and the experiment was terminated on $11^{\text {th }}$ day. The cultures from various groups were stained with $1 \%$ crystal violet in $1 \%$ methanol. The colonies of cells were scored using stereozoom microscope (E Wild M3, Wild Heerbrugg Ltd., Heerbrugg, Switzerland). The clones containing a minimum of 50 or more cells were scored as a colony. The plating efficiency was determined and surviving fraction (SF) calculated. 
The data were fitted on to linear quadratic equation:

$$
S F=\exp -\left[\alpha D+\beta D^{2}\right]
$$

The optimum treatment time for APE exposure was determined on the basis of cell viability and surviving fraction. Treatment of HeLa cells with various concentrations of APE showed a maximum cell kill for $6 \mathrm{~h}$ APE treatment. Therefore, further experiments were carried out using this APE treatment time.

Effect of various concentrations of APE on cell survival and micronuclei formation

The experimental design has been essentially similar to that described above except that HeLa cells were exposed to DMSO or APE for $6 \mathrm{~h}$, thereafter, the APE-containing medium was removed, and the cells were dislodged from the culture flasks by trypsin-EDTA treatment. The cells were divided into two parts and the following studies were carried out:

\section{Clonogenic assay}

One part of the cells was used for clonogenic assay, where 200 cells from each concentration of APE were seeded in quadruplicate. The details of the assay have been described earlier.

\section{Micronucleus assay}

The other part of cells left after clonogenic assay was used for micronucleus study, where $3 \times 10^{5}$ cells were inoculated in triplicate for each drug concentration. The micronuclei were prepared according to the modified method of Fenech \& Morley. ${ }^{28}$ Briefly, the cells were allowed to attach for $6 \mathrm{~h}$; after which the cells were treated with $3 \mu \mathrm{g} / \mathrm{ml}$ of cytochalasin-B to inhibit cytokinesis. The cells were left undisturbed and were allowed to grow for another 14, 24 or $34 \mathrm{~h}$, depending on the assay time. The cell cultures were terminated at 20,30 and $40 \mathrm{~h}$ post-drug-treatment. The medium containing cytochalasin-B was removed; the cells were washed with PBS, dislodged by trypsin EDTA treatment and centrifuged. The cell pellet was disturbed and subjected to mild hypotonic treatment $(0.75 \%$ ammonium oxalate $)$ at $37^{\circ} \mathrm{C}$, centrifuged again and the resultant cell pellet was fixed in Carnoy's fixative 3:1 (methanol:acetic acid). After centrifugation, the cells were resuspended in a small volume of fixative and spread on to precleaned coded slides to avoid observer's bias.

The slides containing cells were stained with $0.125 \%$ acridine orange (BDH, England, Gurr Cat. no. 34001 9704640E) in Sorensen's buffer ( $\mathrm{pH}$ 6.8) and subsequently washed twice in the Sorensen's buffer. The slides mounted in Sorensen's buffer were observed under a fluorescent microscope equipped with 450-490nm BP filter set with excitation at $453 \mathrm{~nm}$ (Carl Zeiss, Photomicroscope III, Oberkochen, Germany) using a 40X Neofluar objective. A minimum of one thousand binucleate cells with well-preserved cytoplasm was scored for each concentration and the frequency of micronucleated binucleate cells (MNBNC) was determined. The micronucleated cells were scored according to the criteria of Kirsch-Volders et al. ${ }^{29,30}$ and Fenech et al. ${ }^{31}$. The data regarding the cell proliferation kinetics were also collected, where the frequencies of mono-, bi-, tri- and tetranucleate cells were determined. The proliferation indices (PI) were calculated from the mean of 4000 cells for each drug concentration.

The PI was calculated as follows:

$$
\mathrm{PI}=(1 \times \mathrm{N})+(2 \times 2 \mathrm{~N})+(3 \times 3 \mathrm{~N})+(4 \times 4 \mathrm{~N}) \div 1000
$$

Where: $\mathrm{N}=$ total mononucleate cells, $2 \mathrm{~N}=$ total binucleate cells, $3 \mathrm{~N}=$ total trinucleate cells, and $4 \mathrm{~N}=$ total tetranucleate cells.
The regression analyses were carried out using for linear and for linear quadratic equations.

\section{Statistical analyses}

The statistical significance between the treatments was analysed using one-way ANOVA for clonogenic, and micronucleus assays as well as for the proliferative indices. The data were confirmed by repetition of the experiments. The test of homogeneity has been applied and data of two experiments did not differ significantly from one another. Hence the data of both the experiments are combined and presented as means. Appropriate post-hoc tests were used for multiple comparisons. Solo 4 (BMDP Statistical Software Inc., Los Angeles, CA) was used for statistical analyses.

\section{Results}

The results are expressed as percent viability, surviving fraction (SF), micronuclei frequency per thousand cells, and cell proliferation indices as mean \pm SEM (standard error of the mean) in Table 1-3 \& Figure 1-5.

\section{Evaluation of optimum treatment time for APE treatment}

Pratt and Willis test: A maximum number of surviving cells (>99\%) were observed in non-drug-treated control group. Treatment of HeLa cells with various concentrations of APE for $0,1,2,4,6,8,12,16$ or $24 \mathrm{~h}$ caused a concentration dependent decline in the number of surviving cells. Similarly, viability of cells declined with the length of treatment time and a maximum reduction in cell viability was observed for $6 \mathrm{~h}$ treatment (Figure 1). Thereafter, the difference between $6 \mathrm{~h}(\mathrm{p}<0.005)$ and other longer treatment times was statistically non-significant (Table 1). However, the effect of treatment time on cell viability was significantly different up to $4 \mathrm{~h}$ in comparison with $6 \mathrm{~h}$ APE treatment (Table 1$)$. The inhibitory concentration $\left(\mathrm{IC}_{50}\right)$ of APE was found to be $25 \mu \mathrm{g} / \mathrm{ml}$ for $6 \mathrm{~h}$ exposure time. Exposure of doxorubicin to HeLa cells also inhibited the viability of cells in a concentration-dependent fashion (Figure 1) akin to APE treatment, except that the highest effect was observed for $10 \mu \mathrm{g} / \mathrm{ml}$ of doxorubicin after $4 \mathrm{~h}$ drug exposure (Table 1).

Clonogenic assay: Treatment of HeLa cells with DMSO for different times did not adversely affect their clonogenicity, as evidenced by nonsignificant changes in the survival of HeLa cells (Figure 2). Exposure of HeLa cells to APE for $0,1,2,4,6,8,12,16$ or $24 \mathrm{~h}$ resulted in a time and concentration-dependent decline in the clonogenicity of cells. A $50 \%$ reduction in the surviving fraction of treated cells was obtained after treatment with $50 \mu \mathrm{g} / \mathrm{ml}$ APE for $1 \mathrm{~h}$. An identical effect was discernible in the cells treated with $25 \mu \mathrm{g} / \mathrm{ml} \mathrm{APE}$ for 6h (Figure 2). Surviving fraction of cells reduced significantly with exposure time up to $6 \mathrm{~h}$ depending on the APE concentration and a highest decline in cell survival was observed for $100 \mu \mathrm{g} / \mathrm{ml}$. An optimum inhibitory concentration $\left(\mathrm{IC}_{50}\right)$ was found to be $25 \mu \mathrm{g} / \mathrm{ml}$ for $6 \mathrm{~h}$ treatment when compared to the non-APE treated controls i.e. 0 concentrations (Figure 2). Since maximum cell killing effect was observed for $6 \mathrm{~h}$ APE exposure, this treatment time was considered as an optimum treatment time and further studies were undertaken using this time for APE treatment. Treatment of HeLa cells with different doxorubicin concentrations also reduced the surviving fraction (SF) of cells in a time dependent manner and a highest reduction of cell survival was observed after $4 \mathrm{~h}$ exposure for $10 \mu \mathrm{g} / \mathrm{ml}$ DOX (Figure 2). 
Table I Effect of different treatment times on the viability of HeLa cells treated with various doses of Aphanamixis polystachya

\begin{tabular}{|c|c|c|c|c|c|c|c|c|c|c|}
\hline \multirow{2}{*}{$\begin{array}{l}\text { Concentration } \\
(\mu \mathrm{g} / \mathrm{ml})\end{array}$} & & \multicolumn{9}{|c|}{$\begin{array}{l}\text { Cell Viability (\%) } \pm \text { SEM } \\
\text { Drug-Treatment Time (h) }\end{array}$} \\
\hline & & 0 & I & 2 & 4 & 6 & 8 & 12 & 16 & 24 \\
\hline \multirow{7}{*}{ APE } & 0 & $99.32 \pm 0.14$ & $99.94 \pm 0.15$ & $99.86 \pm 0.14$ & $99.27 \pm 0.16$ & $99.69 \pm 0.16$ & $98.44 \pm 0.16$ & $98.97 \pm 0.23$ & $99.35 \pm 0.28$ & $99.24 \pm 0.31$ \\
\hline & 5 & $99.57 \pm 0.13$ & $96.85 \pm 0.13$ & $93.42 \pm 0.12$ & $80.74 \pm 0.13$ & $73.54 \pm 0.14$ & $72.18 \pm 0.15$ & $72.16 \pm 0.17$ & $71.30 \pm 0.14$ & $70.42 \pm 0.16$ \\
\hline & 10 & $99.61 \pm 0.15$ & $91.00 \pm 0.13$ & $83.17 \pm 0.13$ & $73.79 \pm 0.13^{a}$ & $66.32 \pm 0.11$ & $65.91 \pm 0.12^{b}$ & $65.58 \pm 0.12^{b}$ & $65.04 \pm 0.12^{b}$ & $64.97 \pm 0.14^{b}$ \\
\hline & 25 & $98.95 \pm 0.14$ & $86.89 \pm 0.13$ & $75.43 \pm 0.1^{b}$ & $66.6 I \pm 0 . I^{c}$ & $52.76 \pm 0.05^{c}$ & $51.49 \pm 0.05^{c}$ & $51.33 \pm 0.05^{c}$ & $50.02 \pm 0.05^{c}$ & $49.61 \pm 0.06$ \\
\hline & 50 & $99.26 \pm 0.15$ & $77.01 \pm 0.12$ & $65.09 \pm 0.1^{\mathrm{b}}$ & $58.53 \pm 0.10^{c}$ & $41.01 \pm 0.05^{c}$ & $40.66 \pm 0.04^{c}$ & $40.39 \pm 0.04^{c}$ & $39.75 \pm 0.04^{c}$ & $39.19 \pm 0.04$ \\
\hline & 75 & $99.48 \pm 0.21$ & $64.72 \pm 0.12$ & $55.01 \pm 0 . I^{b}$ & $47.76 \pm 0.10^{c}$ & $35.05 \pm 0.04^{c}$ & $34.95 \pm 0.03^{c}$ & $34.82 \pm 0.03^{c}$ & $34.52 \pm 0.0$ & $34.11 \pm 0.04$ \\
\hline & 100 & $99.39 \pm 0.29$ & $59.80 \pm 0.12$ & $48.83 \pm 0.1^{b}$ & $39.70 \pm 0.09 c$ & $28.19 \pm 0.03^{c}$ & $27.75 \pm 0.03^{c}$ & $27.52 \pm 0.03^{c}$ & $26.89 \pm 0.03^{c}$ & $26.20 \pm 0.04$ \\
\hline \multirow{6}{*}{ DOX } & 2 & $99.42 \pm 0.32$ & $96.4 I \pm 0.14$ & $89.74 \pm 0.13$ & $82.62 \pm 0.13$ & $82.53 \pm 0.13$ & $82.23 \pm 0.16$ & $82.20 \pm 0.18$ & $81.58 \pm 0.13$ & $80.71 \pm 0.15$ \\
\hline & 4 & $99.49 \pm 0.15$ & $92.52 \pm 0.13$ & $85.25 \pm 0.14$ & $77.34 \pm 0.12^{\mathrm{a}}$ & $77.12 \pm 0.12^{\mathrm{a}}$ & $77.10 \pm 0.13^{a}$ & $77.45 \pm 0.12 b$ & $76.85 \pm 0.1 I^{b}$ & $76.15 \pm 0.12^{\circ}$ \\
\hline & 6 & $99.35 \pm 0.14$ & $89.29 \pm 0.14$ & $84.79 \pm 0.12$ & $70.00 \pm 0.1 I^{c}$ & $70.35 \pm 0.12^{c}$ & $70.18 \pm 0.13^{c}$ & $69.48 \pm 0.13^{c}$ & $68.54 \pm 0.10^{c}$ & $67.65 \pm 0.13^{c}$ \\
\hline & 8 & $99.24 \pm 0.16$ & $85.16 \pm 0.14$ & $79.18 \pm 0.12$ & $59.66 \pm 0.08^{c}$ & $58.06 \pm 0.09 c$ & $57.44 \pm 0.90^{\circ}$ & $56.82 \pm 0.08^{c}$ & $56.34 \pm 0.08^{c}$ & $55.1 I \pm 0.1 I^{\circ}$ \\
\hline & 10 & $99.16 \pm 0.15$ & $82.29 \pm 0.14$ & $71.79 \pm 0.12$ & $52.00 \pm 0.1 I^{\mathrm{c}}$ & $51.65 \pm 0.12^{\mathrm{c}}$ & $51.38 \pm 0.13^{c}$ & $51.40 \pm 0.13^{c}$ & $50.74 \pm 0.10^{c}$ & $50.05 \pm 0.13$ \\
\hline & 12 & $99.08 \pm 0.14$ & $63.28 \pm 0.12$ & $49.68 \pm 0.11$ & $24.69 \pm 0.08^{c}$ & $23.23 \pm 0.08^{c}$ & $22.79 \pm 0.08^{c}$ & $21.97 \pm 0.07^{c}$ & $20.94 \pm 0.08^{c}$ & $19.66 \pm 0.10^{\circ}$ \\
\hline
\end{tabular}

$\mathrm{APE}=$ chloroform fraction of the stem bark of Aphanamixis polystachya $; \mathrm{DOX}=$ doxorubicin, a positive control; and SEM = standard error of the mean . $\mathrm{p}<\mathrm{a}=0.05, \mathrm{~b}=0.0 \mathrm{I}, \mathrm{c}=0.005$, no symbols $=$ not significant when compared with the concurrent non-drug treated group.

$5 \times 104$ log phase HeLa cells were seeded in several culture flasks. On the following day the cells were treated with various doses of CAP for different times as indicated above. After the treatment time the drug-containing medium was replaced with fresh medium and the cultures were re-incubated further up to $72 \mathrm{~h}$ when they were harvested, stained with trypan blue and counted. The results are the mean of three independent trials/drug concentration/treatment time and expressed as \% viability

Table 2 Micronuclei induction in HeLa cells by various concentrations of chloroform extract of Aphanamixis polystachya at different post-treatment times

\begin{tabular}{|c|c|c|c|c|}
\hline \multirow{2}{*}{$\begin{array}{l}\text { Binucleate Cells Bearing } \\
\text { Micronuclei }\end{array}$} & \multirow[t]{2}{*}{ APE $(\mu g / m l)$} & \multicolumn{3}{|c|}{$\begin{array}{l}\text { Frequency of Micronucleated Binucleate Cells per } 1000 \\
\text { Post-Treatment Scoring Time (h) }\end{array}$} \\
\hline & & 20 & 30 & 40 \\
\hline \multirow{8}{*}{ One MN } & 0 & $5.78 \pm 0.63$ & $16.50 \pm 1.66$ & $7.33 \pm 0.80$ \\
\hline & 5 & $8.14 \pm 0.83$ & $20.84 \pm 1.10$ & $12.64 \pm 0.96^{\mathrm{a}}$ \\
\hline & 10 & $11.61 \pm 1.08^{a}$ & $31.25 \pm 2.24^{\mathrm{a}}$ & $23.50 \pm 1.26 b$ \\
\hline & 25 & $25.7 \pm 2.04^{b}$ & $74.67 \pm 5.18^{b}$ & $46.67 \pm 3.47^{b}$ \\
\hline & 50 & $34.8 \mathrm{I} \pm 2.5 \mathrm{I}^{\mathrm{b}}$ & $91.13 \pm 6.20^{\mathrm{b}}$ & $58.50 \pm 3.90^{\mathrm{b}}$ \\
\hline & 75 & $42.33 \pm 3.16^{b}$ & $99.54 \pm 6.1 I^{b}$ & $67.86 \pm 4.47^{c}$ \\
\hline & 100 & $47.48 \pm 3.88^{b}$ & $107.60 \pm 7.32^{b}$ & $75.78 \pm 5.65^{c}$ \\
\hline & r2 & 0.99 & 0.97 & 0.98 \\
\hline \multirow{8}{*}{ Two MN } & 0 & $0.21 \pm 0.03$ & $0.54 \pm 0.07$ & $0.42 \pm 0.03$ \\
\hline & 5 & $1.17 \pm 0.09^{b}$ & $2.40 \pm 0.16^{b}$ & $\mathrm{I} .73 \pm 0.1 \mathrm{I}^{\mathrm{b}}$ \\
\hline & 10 & $2.48 \pm 0.14^{c}$ & $4.64 \pm 0.32^{b}$ & $2.96 \pm 0.20^{b}$ \\
\hline & 25 & $5.16 \pm 0.37 c$ & $8.02 \pm 0.52^{b}$ & $6.12 \pm 0.48^{b}$ \\
\hline & 50 & $6.31 \pm 0.38^{c}$ & $9.73 \pm 0.73^{b}$ & $7.78 \pm 0.56^{b}$ \\
\hline & 75 & $6.90 \pm 0.48^{c}$ & $10.80 \pm 0.80 \mathrm{~b}$ & $8.84 \pm 0.65 b$ \\
\hline & 100 & $7.86 \pm 0.50 c$ & $12.92 \pm 0.94^{b}$ & $9.96 \pm 0.76^{b}$ \\
\hline & r2 & 0.96 & 0.95 & 0.97 \\
\hline \multirow{8}{*}{ Multiple MN } & 0 & $0.30 \pm 0.03$ & $1.12 \pm 0.10$ & $0.48 \pm 0.03$ \\
\hline & 5 & $0.83 \pm 0.05^{b}$ & $1.60 \pm 0.08$ & $1.07 \pm 0.06^{b}$ \\
\hline & 10 & $1.26 \pm 0.08^{b}$ & $2.06 \pm 0.14 a$ & $1.61 \pm 0.09^{b}$ \\
\hline & 25 & $2.20 \pm 0.12 c$ & $3.48 \pm 0.23^{b}$ & $2.56 \pm 0.14 b$ \\
\hline & 50 & $2.50 \pm 0.13 c$ & $4.10 \pm 0.31^{b}$ & $3.06 \pm 0.21^{b}$ \\
\hline & 75 & $3.06 \pm 0.17 c$ & $4.7 I \pm 0.35^{b}$ & $3.61 \pm 0.36^{b}$ \\
\hline & 100 & $3.38 \pm 0.23 c$ & $5.43 \pm 0.43^{b}$ & $4.12 \pm 0.37^{b}$ \\
\hline & r2 & 0.96 & 0.97 & 0.97 \\
\hline \multirow{8}{*}{ Total MN } & 0 & $6.29 \pm 0.63$ & $18.16 \pm 1.36$ & $8.23 \pm 0.96$ \\
\hline & 5 & $10.14 \pm 0.86$ & $24.84 \pm 1.84$ & $|5.44 \pm| .22 \mathrm{a}$ \\
\hline & 10 & $15.35 \pm 1.2 \mathrm{la}$ & $37.95 \pm 2.3 \mathrm{Ia}$ & $28.07 \pm 2.40 \mathrm{a}$ \\
\hline & 25 & $33.06 \pm 2.16^{\mathrm{b}}$ & $86.17 \pm 3.62 c$ & $55.35 \pm 3.75^{b}$ \\
\hline & 50 & $43.62 \pm 2.42^{c}$ & $104.96 \pm 4.77^{c}$ & $69.34 \pm 4.30^{\mathrm{b}}$ \\
\hline & 75 & $52.29 \pm 2.7 \mathrm{I}^{\mathrm{c}}$ & $1 / 5.05 \pm 5.33^{c}$ & $80.31 \pm 4.27^{c}$ \\
\hline & 100 & $58.72 \pm 3.10^{c}$ & $125.95 \pm 5.19^{c}$ & $89.86 \pm 4.66^{c}$ \\
\hline & r2 & 0.99 & 0.97 & 0.98 \\
\hline
\end{tabular}

$\mathrm{P}<\mathrm{a}=0.05, \mathrm{~b}=0.0 \mathrm{I}, \mathrm{c}=0.005$, no symbols $=$ not significant when compared to non-drug treated control.

APE $=$ Chloroform extract of the stem bark of Aphanamixis polystachya; SEM = Standard error of the mean;

$\mathrm{MN}=$ micronuclei; $r 2$ = coefficient of correlation 
Table 3 Alteration in the cell proliferation kinetics of HeLa exposured of different concentrations of choloroform extract of Aphanamixis polystachya for $6 \mathrm{~h}$

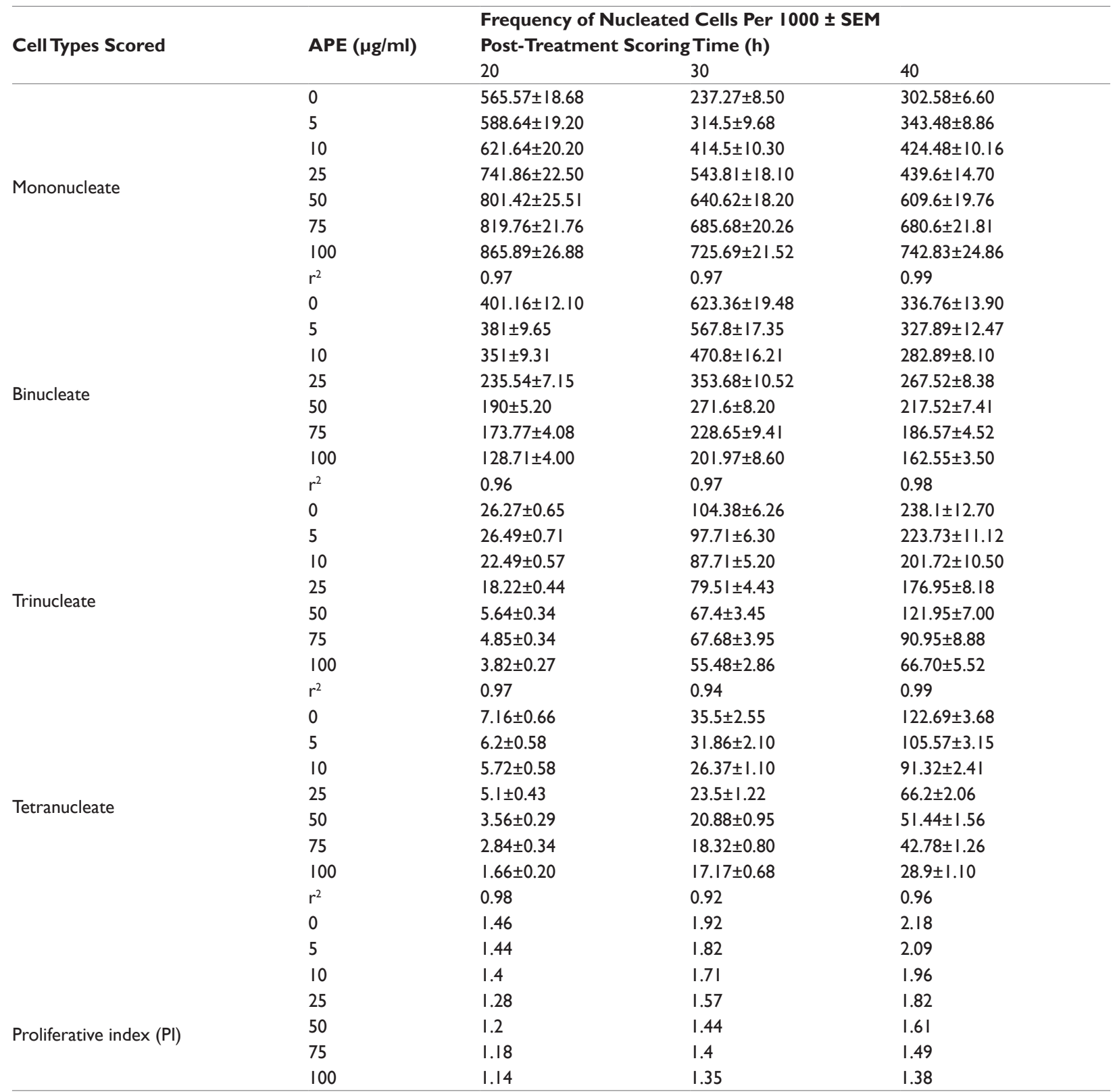

$\mathrm{APE}=$ chloroform fraction of the stem bark of Aphanamixis polystachya $; \mathrm{SEM}=$ standard error of the mean;

r2 = coefficient of correlation

Proliferation kinetics (PI), a measure of cell division kinetics was calculated from the mean of at least 4000 cells/drug concentration using the formula:

$\mathrm{PI}=[(\mathrm{I} \times \mathrm{N})+(2 \times 2 \mathrm{~N})+(3 \times 3 \mathrm{~N})+(4 \times 4 \mathrm{~N})] \div 1000$

$\mathrm{N}=$ mononucleated cells; $2 \mathrm{~N}=$ binucleated cells; $3 \mathrm{~N}=$ trinucleated cells; $4 \mathrm{~N}=$ tetranucleated cells.

Effect of various concentrations of APE on cell survival and micronuclei formation

Clonogenic assay: Treatment of HeLa cells with various concentrations of APE resulted in a concentration- and time-dependent decline in the SF (Figure 3). The lowest concentration of APE i.e. $5 \mu \mathrm{g} /$ $\mathrm{ml}$, reduced the SF of cells by $10 \%$, whereas increasing concentration of APE resulted in a corresponding decline in the clonogenicity of HeLa cells until a nadir was reached at $100 \mu \mathrm{g} / \mathrm{ml} \mathrm{APE}$, the maximum concentration evaluated for cytotoxicity (Figure 3). Treatment of HeLa cells with $25 \mu \mathrm{g} / \mathrm{ml}$ APE resulted in a $40 \%$ reduction in the cell survival when compared with $5 \mu \mathrm{g} / \mathrm{ml}$ APE treatment, whereas this decline in SF was approximately $50 \%$ when compared with the non-APE treated control (Figure 3). Hence this concentration was considered as $\mathrm{IC}_{50}$ concentration of APE.

\section{Cell proliferation index}

The base line proliferation index (PI) of HeLa cells was found to be 2 at all the post-treatment times studied. The frequency of mononucleate cells showed a concentration-dependent elevation (Figure 5a), which was significantly higher at all the concentrations of $\mathrm{APE}$ at all the post-treatment times when compared with the non-drug- 
treated controls (Table 3). In contrast, treatment of HeLa cells with various concentrations of APE resulted in a concentration-dependent decline in the frequency of binucleate cells at all the post-treatment times (Figure $5 \mathrm{~b}$ ). This decline in binucleate cells was significantly higher for all the APE concentrations at 20,30 and 40h post-treatment resulting in a 50 to $90 \%$ reduction in PI (1.5 and 1.14) in the cells treated with 25 and $100 \mu \mathrm{g} / \mathrm{ml} \mathrm{APE}$, respectively at $20 \mathrm{~h}$ post-treatment (Table 3). The frequency of multinucleate (tri and tetranucleate) cells also showed a concentration-dependent decline indicating a block in the cell division. Multinucleate cells were almost absent at $20 \mathrm{~h}$ after exposure to $25-100 \mu \mathrm{g} / \mathrm{ml}$ APE (Figure 5c \& 5d). This decline in multinucleate cells was significant at 20 and $30 \mathrm{~h}$ post-treatment when compared with non-drug treated controls (Table 3). The PI showed a time dependent rise for all the APE concentrations and a maximum PI was recorded at $40 \mathrm{~h}$ post-APE treatment (Figure 5).
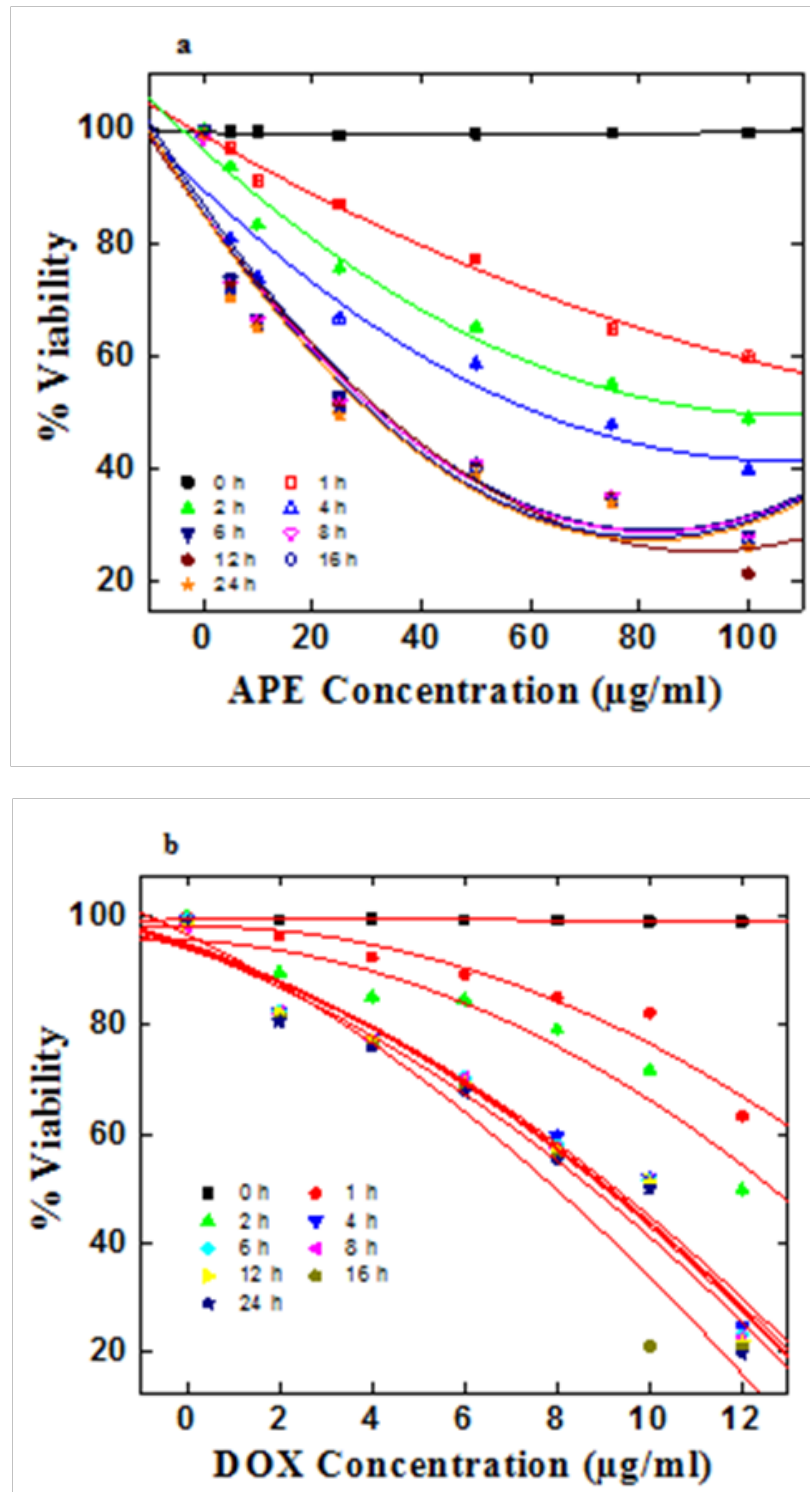

Figure I Effect of different treatment times on the percent viability of HeLa cells treated with different concentrations of chloroform extract of Aphanamixis polystachya (a) or doxorubicin (b) (used as positive control) as determined by Pratt and Willis test.
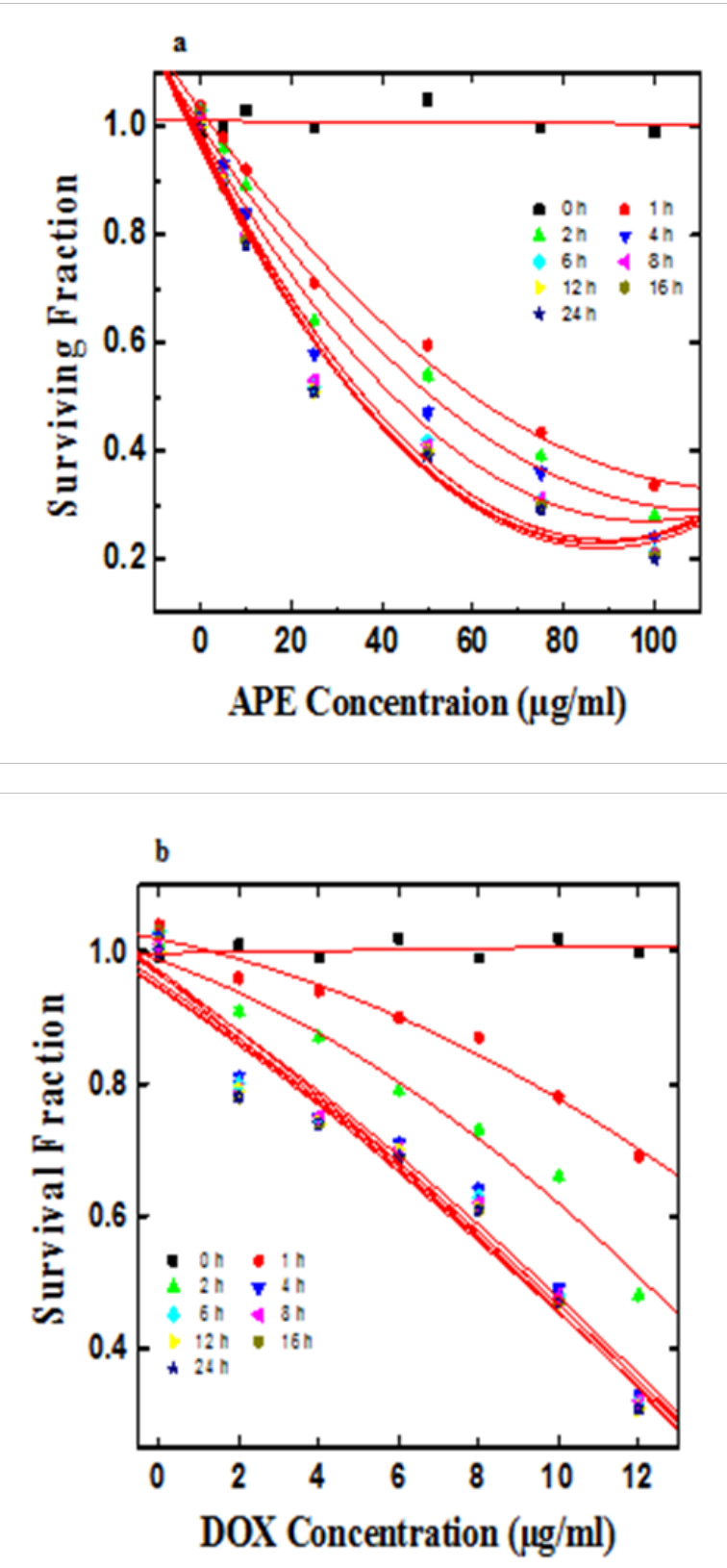

Figure 2 Effect of different treatment times on the survival of HeLa cells treated with different concentrations of chloroform extract of Aphanamixis polystachya (a) or doxorubicin (b) (used as positive control).

\section{Biological response}

The biological response was evaluated by correlating the cell survival and micronuclei induction, where the surviving fraction was plotted on $\mathrm{X}$-axis and micronuclei frequency on Y-axis. The dose response relationship was linear $\left(\mathrm{r}^{2}=0.97,0.98,0.97\right.$ for 20,30 and $40 \mathrm{~h}$, respectively). The cell survival declined with the increasing micronuclei frequency indicating an inverse relationship between surviving fraction and micronuclei formation (Figure 6).

\section{Discussion}

Due to the identification of several anticancer drugs from various plants, random screening for compounds leading to candidates for 
anticancer agents is continually performed, despite recent progress in molecular and cellular research on cancer therapy. ${ }^{32}$ The plants synthesize a variety of chemicals as secondary metabolites to combat stress, fight against the predators, as nutrients and to carry out various physiological activities. ${ }^{33}$ These plant metabolites have been useful in human healthcare in various ways and many of these metabolites have provided modern anticancer drugs. ${ }^{32}$ Therefore, it is necessary to screen medicinal plants for new drug discovery and also for combinatorial chemistry. The antineoplastic activity of the stem bark extract of Aphanamixis polystachya (APE) has been evaluated in cultured HeLa cells in the present study.

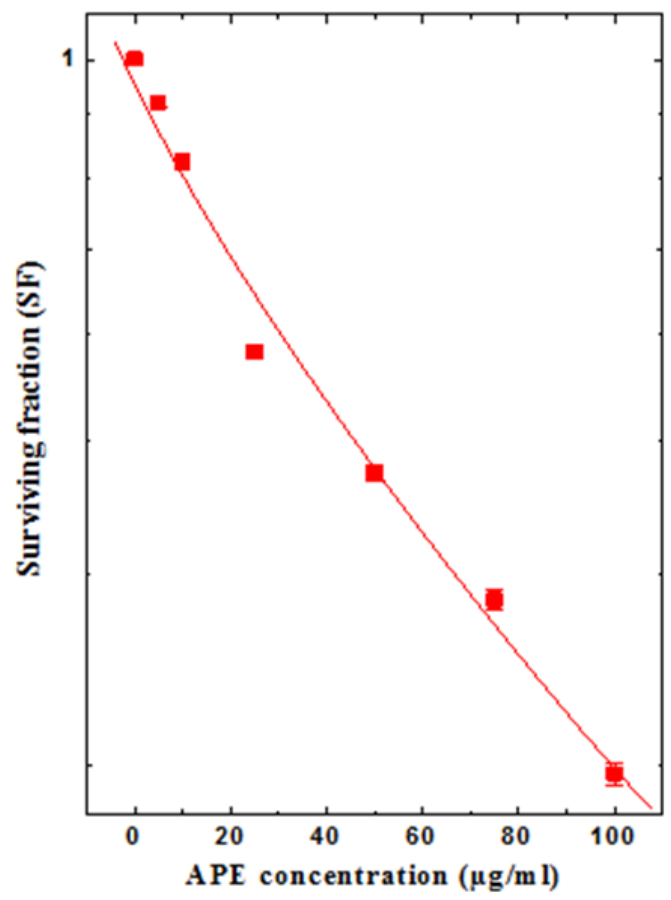

Figure 3 Effect of different concentration of chloroform extract of Aphanamixis polystachya on the survival of HeLa cells.

HeLa cells are frequently employed as model cancer cells to determine the cytotoxic effects of chemical or physical agents. ${ }^{34}$ The cytotoxic effect of APE increased with time up to $6 \mathrm{~h}$ post-treatment and remained almost unaltered thereafter as evident by cell viability and clonogenic assays. An identical effect was observed earlier when HeLa cells were treated with doxorubicin, acyclovir, azidothymidine or extract of Tinospora cordifolia. ${ }^{8,21,35,36}$ The cytotoxic effect of APE increased with increasing concentrations and an $\mathrm{IC}_{50}$ concentration was found to be $25 \mu \mathrm{g} / \mathrm{ml}$. An almost complete inhibition of cell division was discernible at a concentration of $100 \mu \mathrm{g} / \mathrm{ml} \mathrm{APE}$ as indicated by low PI and very low clonogenicity. The reports regarding the cytotoxic effect of APE in vitro are unavailable. However, triterpenoid amooranin present in Aphanamixis polystachya has been reported to be cytotoxic to HeLa, MCF-7 and SW620 human colon carcinoma cells in vitro. ${ }^{37,38}$ The alcoholic extract of the stem bark of Aphanamixis polystachya (AP) showed cytotoxic activity on Ehrlich ascites carcinoma cells in vivo. ${ }^{15}$ Similarly, other antineoplastic agents like, doxorubicin, vinblastine, taxol and teniposide (VM-26) have been reported to induce cytotoxicity in V79 cells. ${ }^{11,39-42}$ Treatment of HeLa, MCF-7, HL 60, or KB cells to alcoholic extract of the stem bark of Alstonia scholaris or echitamine chloride have been reported to induce cytotoxicity earlier. ${ }^{8,20,43,44}$ The cytotoxic effect of APE is reflected in proliferation indecies (PI), where a concentration dependent reduction in PI was observed at all post-treatment times in cells treated with various concentrations of APE. Its petroleum ether extract has been reported to be cytotoxic in cultured human breast cell lines earlier. ${ }^{45}$

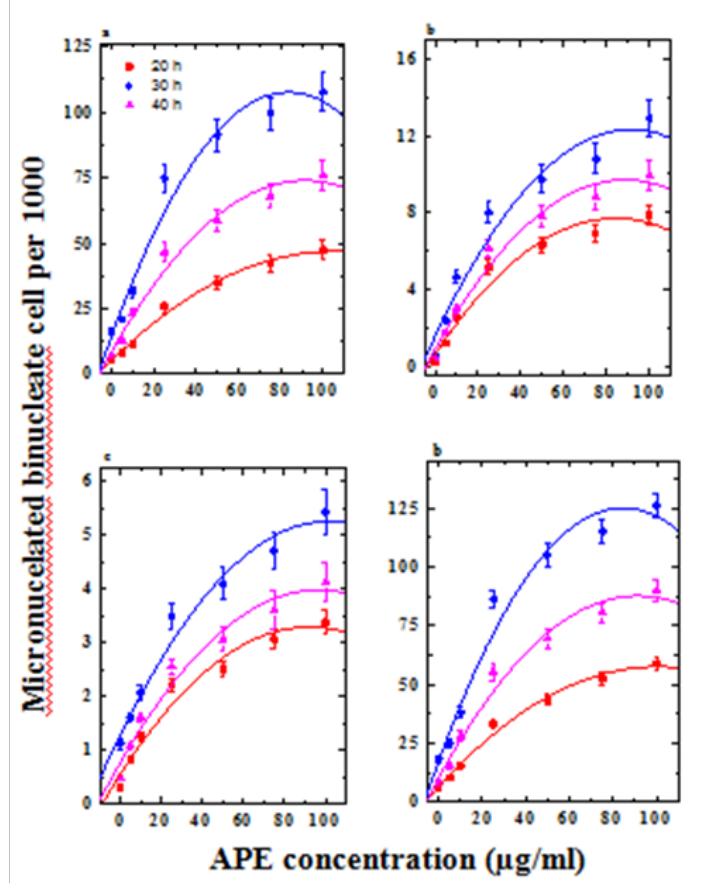

Figure $4 \mathrm{Effect}$ of various concentrations of chloroform extract of Aphanamixis polystachya on the micronuclei formation in HeLa cells at different posttreatment times: a: one $\mathrm{MN}$; b: two $\mathrm{MN}$; c: multiple $\mathrm{MN}$ and d; total $\mathrm{MN}$ Closed squares, $20 \mathrm{~h}$; Closed circles, $30 \mathrm{~h}$; Closed triangles, $40 \mathrm{~h}$ post-treatment.

The chemotherapeutic agents usually act by eliciting DNA damage by inducing single or double strand breaks or other types of DNA damages that may be converted into DNA double strand breaks that prove fatal to the cells. Therefore we were interested to determine whether the APE is able to damage the cellular DNA or not and the observed cell killing effect is due to DNA damage? The micronuclei are surrogate markers of DNA damage, which are produced by acentric fragments or a whole chromosome that could not attach to the mitotic spindle during cell division and are excluded from the main nuclei or due to defective spindle fibers or kinetochores. The mechanisms involved in the formation of micronuclei may be different depending on the action of the drug. They may be produced due to chromosome breakage (clastogenesis) or spindle disruption (aneugenesis). ${ }^{3,4}$ The micronuclei can be studied with ease and do not require a great skill unlike chromosome aberrations and their study provides the information which is forthcoming from the analysis of chromosome aberrations. ${ }^{11}$

Exposure of HeLa cells to various concentrations of APE resulted in a concentration dependent elevation in the frequency of micronuclei. APE not only induced one MNBNC, but also cells bearing two and multiple MNBNC, indicating that it induced complex multiply site of DNA damage of non-reparable nature. The reports regarding the induction of micronuclei by APE are unavailable. This is probably the first report describing the APE-induced DNA damage in HeLa cells. Similarly, doxorubicin, extract of Tinospora cordifolia, acyclovir and azidothymidine have been reported to increase the frequency of micronuclei in a concentration-dependent manner in 
HeLa cells earlier. ${ }^{8-10,35}$ The treatment of V79 cells with doxorubicin has been found to increase the micronuclei frequency in concentration dependent manner. ${ }^{11}$ The other chemotherapeutic drugs including vindesine, vinblastine, taxol and teniposide increased the frequency of micronuclei in V79 cells in a concentration dependent fashion. ${ }^{39-42,46}$ The frequency of MNBNC increased with time, and a peak was observed at $30 \mathrm{~h}$ post-treatment which may be due to the APE-induced cell cycle delay. A similar effect has been reported earlier in HeLa cells. ${ }^{8}$ The micronuclei frequency will be highest immediately after first cell division, which seems to be the reason of maximum frequency of micronuclei at $30 \mathrm{~h}$ post treatment and decline with subsequent cell division. The decline in micronuclei at later scoring times is due to the dilution owing to cell division or cell death as observed in the present study. The results of cell proliferation indices support this contention.
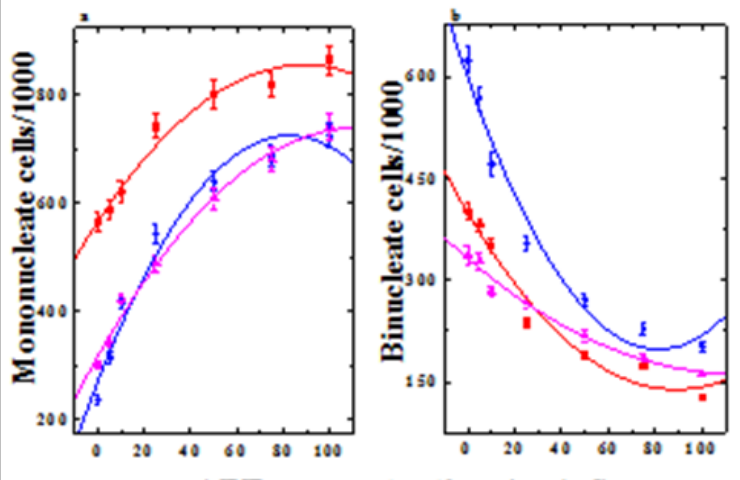

APE concentration $(\mu \mathrm{g} / \mathrm{ml})$
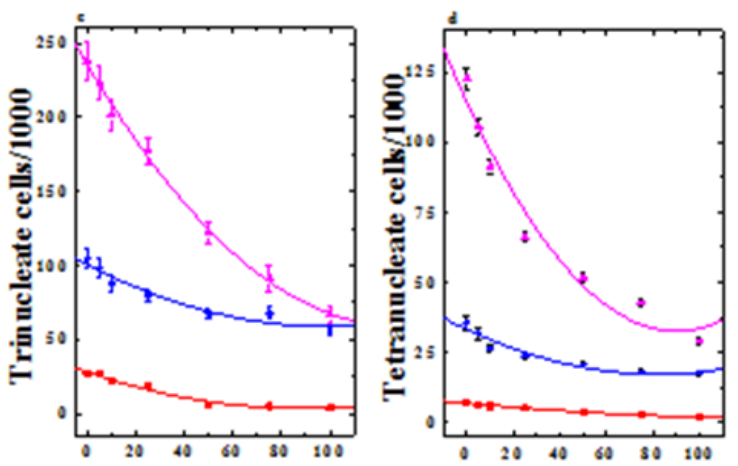

APE concentration $(\mu \mathrm{g} / \mathrm{ml})$

Figure 5 Effect of different concentrations of CAP on the HeLa cell proliferation kinetics at various post-treatment times. a: mononucleate cells; b: binucleate cells;c: trinucleate cells and d: tetranucleate cells. Closed squares, 20 h; Closed circles, $30 \mathrm{~h}$; Closed triangles, $40 \mathrm{~h}$ post-treatment.

Micronuclei induction and cell survival are found to be closely related. This is expected as the micronuclei are the surrogate marker of DNA damage and cells expressing DNA damage are dying cells. Once the cells express MN they lose clonogenic potential owing to the loss of significant amount of genome and eventually die. The nuclear alterations and micronuclei formation are the major lethal events resulting in the cell killing of HeLa cells. ${ }^{11,47}$ This is supported by a decline in surviving fraction with increasing MNBNC in the present study, indicating an inverse relationship between cell survival and MNBNC induction. The relationship between micronuclei induction and cell survival has been linear. A similar relationship has been reported for HeLa cells after treatment with various doses of acyclovir and azidothymidine. ${ }^{9}$ However, a linear quadratic relationship has also been reported for HeLa cells treated with doxorubicin or Tinospora cordifolia ${ }^{8,9}$ and also for V79 cells treated with various doses of taxol, vindesine or teniposide or doxorubicin..$^{11,39-42}$ In contrast, Bush $\&$ McMillan $^{48}$ did not find any relationship between micronuclei induction and cell survival.

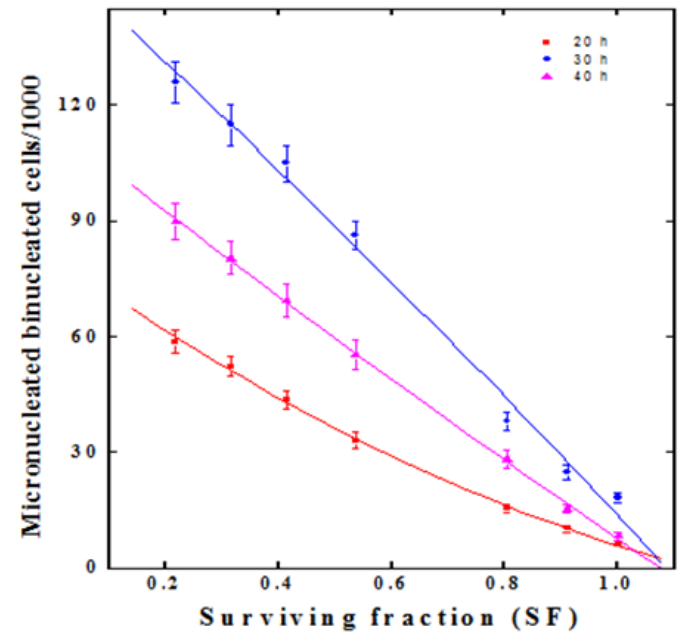

Figure 6 Correlation between cell survival and micronuclei induction in HeLa cells exposed to different concentrations of CAP at different post-treatment times.

The frequency of micronuclei in L929 cells was influenced by drugs like etoposide (topoisomerase II inhibitor) and H-7, Go6983 (PKC inhibitors) known to play an important role in signaling and execution of apoptosis suggesting that micronuclei induction mediated by topoisomerase II and protein kinase pathways leads to the formation of apoptotic cells leading to cell death. ${ }^{49} \mathrm{~A}$ wide range of anticancer agents like, mitomycin $\mathrm{C}$, doxorubicin, epirubicin, cisplatin, carboplatin, etoposide, vincristine, 5-fluorouracil, methotrexate, nimustine and dacarbazine have been reported to induce micronuclei in SCCVII murine carcinoma cells, where a good correlation between the formation of micronuclei and cell survival has been reported. ${ }^{6}$ Similarly, cisplatin and 5-fluorouracil have been found to increase micronuclei and reduce clonogenicity of rodent ovarian carcinoma cells. ${ }^{50}$

The exact mechanism of action of APE is not known. The increased cytotoxicity of APE in HeLa cells may not be due to a single mechanism, but may be due to the operation of multiple mechanisms in concert with one another. Depletion in clonogenicity may mainly be due to the initiation of DNA damage by APE. This contention is supported by a concentration-dependent rise in the MNBNC frequency in HeLa cells in the present study. Due to a significant loss of genome, the APE treatment may have killed HeLa cells efficiently. This DNA damage may have been caused by the induction of oxidative stress by APE that in turn would have induced free radicals thereby attacking the genome. Oxidative stress caused by biochemical dysfunction like glutathione ${ }^{50}$ depletion results in chromatin dysfunction such as single strand and double strand DNA fragmentation leading to cell death. Under depleted GSH condition, endogenously generated hydrogen peroxide might be converted into hydroxyl free radicals. These hydroxyl radicals cause lipid peroxidation and in addition result in the formation of giant DNA fragments and internucleosomal DNA fragments which ultimately drive the cell to necrosis or apoptosis, respectively. ${ }^{51}$ The APE treatment may also have stimulated apoptosis of cells thereby reducing the clonogenicity. In the present study, APE has induced apoptosis after $6 \mathrm{~h}$ treatment where $15 \%$ of the exposed 
cells became apoptotic (data not shown). Amooranin, a triterpenoid present in Aphanamixis polystachya has been reported to induce DNA damage and apoptosis earlier. ${ }^{37}$ APE treatment may also arrest the cells in $\mathrm{G} 2+\mathrm{M}$ phase and killing them subsequently. Depletion in the proliferation index indicates that APE treatment may be doing so in reality. Amooranin has been reported to arrest cells in $\mathrm{G} 2+\mathrm{M}$ phase. ${ }^{52}$ Inhibition of CDK2, CDK4 and serine/threonine kinases may have also contributed to its cytotoxic activity. The flavopiridol, ${ }^{53} \mathrm{a}$ semisynthetic derivative of rohitukine has been reported to inhibit CDK2 CDK2, CDK4 and serine/threonine kinases. ${ }^{54-56}$ The observed antineoplastic action of APE may be due to inhibition of NF- $\kappa \mathrm{B}$, and COX-II. Amooranin has been found to suppress NF- $\mathrm{kB}$, and COX-II activation. ${ }^{38,57}$ The suppression of topoisomerase II activity by APE is also not ruled out as it produced micronuclei efficiently. Since topoisomerase II plays an important role during replication. It is also speculated that APE may have down regulated the Nrf2 gene that may have increased the oxidative stress in HeLa cell leading to effective cell kill..$^{58}$

The DNA damaging and cell killing effects of APE may be partially attributed to the presence of alkaloids rohitukin, amooranin, amoorastatin and $12 \alpha$-hydroxyamoorastatin, which have been reported to kill neoplastic cells. ${ }^{23}$ The action of APE may not only be due to the presence of amooranin and rohitukin alkaloids but may also be due to the presence of complex limonoids like, polystachin, prieurianin, hispidin $C$, aphanamixin and aphananin ${ }^{23,24,59-64}$ whose concerted action may have increased the DNA damage and greater cell kill in the present study.

\section{Conclusion}

APE treatment induced cytotoxic effects in HeLa cells in a concentration-dependent decline in the clonogenicity of cells with an $\mathrm{IC}_{50}$ of $25 \mu \mathrm{g} / \mathrm{ml}$. The cytotoxic effect of APE may be due to induction of DNA damage in the form of micronuclei and induction of apoptosis. The depletion in GSH might have induced oxidative stress and the free radicals leading to DNA damage and ultimately to cell death. APE may also have induced cell cycle blockage at $\mathrm{G}^{2}+\mathrm{M}$ phase. The inhibition of topoisomerase may have contributed to increased DNA double strand breaks and subsequently micronuclei formation by APE in HeLa cells. The APE may have also suppressed the activation of NF- $\mathrm{KB}$, COX-II and Nrf2 genes, which may have contributed in various ways to increase its cell killing effect. The cytotoxic effects of APE may be due to the presence of alkaloids including alkaloids rohitukin, amooranin, amoorastatin and 12 $\alpha$-hydroxyamoorastatin and complex liminoids in it.

\section{Ackowledgements}

The authors are thankful to the Council of Scientific and Industrial Research, Indian Council of Medical Research, Govt. of India for extending the financial support to carry out this study.

\section{Conflicts of interest}

Author declares there are no conflicts of interest.

\section{Funding}

None.

\section{References}

1. Morton LM, Swerdlow AJ, Schaapveld M, et al. Current knowledge and future research directions in treatment-related second primary malignancies. EJC supplements. 2014;12(1):5-17.
2. Cragg GM, Newman DJ. Natural products: a continuing source of novel drug leads. Biochim Biophys Acta. 2013;1830(6):3670-3695.

3. Heddle JA, Hite M, Kirkhart B, et al. The induction of micronuclei as a measure of genotoxicity. A report of the U.S. Environmental Protection Agency Gene-Tox Program. Mutat Res. 1983;123(1):61-118.

4. Majer BJ, Laky B, Knasmuller S, et al. Use of the micronucleus assay with exfoliated epithelial cells as a biomarker for monitoring individuals at elevated risk of genetic damage and in chemoprevention trials. Mutat Res. 2011;489(2-3):147-172.

5. Valent A, Benard J, Clausse B, et al. In vivo elimination of acentric double minutes containing amplified MYCN from neuroblastoma tumor cells through the formation of micronuclei. Am J Pathol. 2001;158(5):1579-1584.

6. Jeremic B, Shibamoto Y, Abe M. Assessment of micronucleus induction in murine SCCVII cells treated with various anticancer agents. Chemotherapy. 1996;42(4):266-272.

7. Driessens G, Harsan L, Browaeys P, et al. Assessment of in vivo chemotherapy-induced DNA damage in a p53-mutated rat tumor by micronuclei assay. Ann N Y Acad Sci. 2003;1010:775-779.

8. Jagetia GC, Nayak V. Micronuclei-induction and its correlation to cell survival in HeLa cells treated with different doses of adriamycin. Cancer Lett. 1996;110(1-2):123-128.

9. Jagetia GC, Aruna R. Effect of various concentrations of acyclovir on cell survival and micronuclei induction on cultured HeLa cells. Mutat Res. 1999;446(2):155-165.

10. Jagetia GC, Nayak V, Vidyasagar MS. Evaluation of the antineoplastic activity of Guduchi (Tinospora cordifolia) in cultured HeLa cells. Cancer lett. 1998;127(1-2):71-82.

11. Jagetia G, Venkatesh P. Bael, Aegle marmelos (L.) Correa, an Indian medicinal plant protects V79 cells against the genotoxic effect of doxorubicin. Int J Genet Mol Biol. 2015;7(5):32-46.

12. Tilburt JC, Kaptchuk TJ. Herbal medicine research and global health: an ethical analysis. Bull World Health Organ. 2008;86(8):594-599.

13. Shantabi L, Jagetia GC. Phytochemical profiling of kam-sabut, Croton caudatus Geiseler. RRJ Bot Sci. 2015;4(1).

14. Jagetia GC. Radioprotective potential of plants and herbs against the effects of ionizing radiations. J Clin Biochem Nutr. 2007;40(2):74-81.

15. Jagetia GC, Venkatesha VA. Preclinical Determination of the Anticancer Activity of Rohituka (Aphanamixis polystachya)in Ehrlich Ascites Tumor-Bearing Mice. Med Aromatic Plant Sci Biotechnol. 2012;6(Special Issue 2):42-51.

16. Chopra RN, Nayar SL, Chopra IC. Glossary of Indian Medicinal Plants. Council of Scientific \& Industrial Research, New Delhi, India. 1956.

17. Srivastava SK, Agnihotri VK. New glycosides from the stem bark of Aphanamixis polystachya. Cur Sci. 1985;54(1):38-40.

18. Rabi T, Gupta RC. Antitumor and cytotoxic investigation of Amoora rohituka. Int J Pharmacog. 1995;33(4):359-361.

19. Dhar ML, Dhar MM, Dhawan BN, et al. Screening of Indian Plants for biological activity I. Ind J Exp Biol . 1968;6(4):232-247.

20. Jagetia GC, Venkatesha VA. Enhancement of radiation effect by Aphanamixis polystachya in mice transplanted with Ehrlich ascites carcinoma. Biol Pharm Bull. 2005;28(1):69-77.

21. Jagetia GC, Venkatesha VA. Treatment of mice with stem bark extract of Aphanamixis polystachya reduces radiation-induced chromosome damage.Int J Radiat Biol. 2006;82(3):197-209.

22. Polonsky J, Varon Z, Marazano C, et al. The structure of amoorastatone and the cytotoxic limonoid 12-hydroxyamoorastatin. Experientia. 1979;35(8):987-989. 
23. Harmon AD, Weiss U, Silverton JV. The structure of rohitukine, the main alkaloid of Amoora rohituka (Syn. Aphanamixis polystachya) (Maliaceae). Tetrahedron Lett. 1979;8(1):721-724.

24. Mulholland DA, Naidoo N. Limonoids from Aphanamixis polystachya Phytochem. 1999;51:927-930.

25. Ahn JW, Sang-Un Choi, Chong-Ock Lee. Cytotoxic limonoids from Melia azedarachta var. japonica. Phytochem. 1994;36(6):1493-1496.

26. Pratt RM, Willis WD. In vitro screening assay for teratogens using growth inhibition of human embryonic cells. Proc Natl Acad Sci. 1985;82(17):5791-5794.

27. Puck TT, Marcus PI. A rapid method for viable cell titration and clone production with HeLa cells in tissue culture. The use of X-irradiated cells to supply conditioning factors. Proc Natl Acad Sci. 1955;41(7):432-437.

28. Fenech M, Morley AA. Measurement of micronuclei in lymphocytes. Mutat Res. 1985;147(1-2):29-36.

29. Kirsch-Volders M, Sofuni T, Aardema M, et al. Report from the in vitro micronucleus assay working group. Environ Mol Mutagen. 2000;35(3):167-172.

30. Kirsch-Volders M, Sofuni T, Aardema M, et al. Report from the in vitro micronucleus assay working group. Mutat Res. 2003;540(2):153-163.

31. Fenech M, Chang WP, Kirsch-Volders M, et al. Human MicronNucleus project HUMN project: detailed description of the scoring criteria for the cytokinesis-block micronucleus assay using isolated human lymphocyte cultures. Mutat Res. 2003;534(1-2):65-75.

32. Kingworm AD, Pan L, Fletcher JN, et al. The relevance of higher plants in lead compound discovery programs. J Nat Prod. 2011;74(6):1539-1555.

33. Cseke LJ, Kirakosya A, Kaufman PB, et al. Natural products from plants. 2nd edn. Taylor \& Francis CRC Press, USA. 2006.

34. Masters JR. HeLa cells 50 years on: the good, the bad and the ugly. Nat Rev Cancer. 2002;2(4):315-319.

35. Aruna R, Jagetia GC. Azidothymidine induces dose dependent increase in the micronuclei formation in cultured HeLa cells. Pharmazie. 2001;56(6):492-500.

36. Jagetia GC, Adiga SK. Influence of vindesine exposure on the micronucleus formation and cell survival in V79 cells. Mutat Res 1998;421(1):55-63.

37. Rabi T, Ramachandran C, Fonseca HB, et al. Novel drug amooranin induces apoptosis through caspase activity in human breast carcinoma cell lines. Breast Cancer Res Treat. 2003;80(3):321-330.

38. Ramachandran C, Nair PK, Alamo A, et al. Anticancer effects of amooranin in human colon carcinoma cell line in vitro and in nude mice xenografts. Int J Cancer. 2006;119(10):2443-2454.

39. Jagetia GC, Jacob PS. The influence of vinblastine treatment on the formation of radiation-induced micronuclei in mouse bone marrow. Hereditas. 1994;120(1):51-59.

40. Jagetia GC, Adiga SK. Influence of various concentration of taxol on cell survival, micronuclei induction and LDH activity in cultured V79 cells. Cancer lett. 1995;96(2):195-200.

41. Jagetia GC, Adiga SK. Effect of various concentration of teniposide (VM-26) on the cell survival, micronuclei induction and lactate dehydrogenase activity on V79 cells. Toxicology. 1999;138(1):29-41.

42. Chan LL, George S, Ahmad I, et al. Cytotoxicity Effects of Amoora rohituka and chittagonga on Breast and Pancreatic Cancer Cells. Evid Complement Alternat. 2011

43. Adiga SK, Jagetia GC. Correlation between cell survival, micronucleiinduction, and LDH activity in V79 cells treated with teniposide (VM26) before exposure to different doses of $\gamma$-radiation. Toxicology Letters.
1999;109(1-2):31-41.

44. Rycke JD, Sert V, Comayras C, et al. Sequence of lethal events in HeLa cells exposed to the G2 blocking cytolethal distending toxin. European J Cell Biol. 2000;79(3):192-201.

45. Bush C, McMillan TJ. Micronucleus formation in human tumour cells: lack of correlation with radiosensitivity. $\mathrm{Br} J$ Cancer. 1993;67(1):102-106.

46. Abend M, Frombeck S, Van Beuningen D. Indications for an active process underlying spontaneous and radiation-induced micronucleation in L929 cells. Int J Radiat Biol. 1999;75(12):1567-1578.

47. Truter EJ, Santos AS, Els WJ. Correlation between cell survival, clonogenic activity and micronuclei induction in dmba-oc-1r cells treated with immunospecific albumin microspheres containing cisplatin and 5-fluorouracil. Cell Biol Int. 2013;26(6):505-516.

48. Lai GM, Ozols RF, Young RC, et al. Effect of glutathione on DNA repair in cisplatin-resistant human ovarian cencer cell lines. J Nat Cancer Inst 1989;81(7):535-539.

49. Meister A, Anderson ME. Glutathione. Annu Rev Biochem. $1983 ; 52: 711-760$.

50. Higuchi Y. Glutathione depletion-induced chromosomal DNA fragmentation associated with apoptosis and necrosis. J Cell Mol Med. 2004;8(4):455-464.

51. Ramachandran C, Rabi T, Fonseca HB, et al. Novel plant triterpenoid drug amooranin overcomes multidrug resistance in human leukemia and colon carcinoma cell lines. Int J Cancer. 2003;105(6):784-789.

52. Arguello F, Alexander M, Sterry JA, et al. Flavopiridol induces apoptosis of normal lymphoid cells, causes immunosuppression, and has potent antitumor activity in vivo against human leukemia and lymphoma xenografts. Blood. 998;91(7):2482-2490.

53. Kaur G, Stevenson SM, Sebers S, et al. Growth inhibition with reversible cell cycle arrest of carcinoma cells by flavone L86-8275. J Natl Cancer Inst. 1992;84(22):1736-1740.

54. Losiewicz MD, Carlson BA, Kaur G. Potent inhibition of CDC2 kinase activity by the flavonoid L86-8275. Biochem Biophys Res Commun. 1994;201(2):589-595.

55. Rabi T, Huwiler A, Zangemeister-Wittke U. AMR-Me inhibits PI3K/ Akt signaling in hormone-dependent MCF-7 breast cancer cells and inactivates NF- $\mathrm{BB}$ in hormone-independent MDA-MB-231 cells. Mol Carcinogen. 2014;53(7):578-588.

56. Stopper H, Boos G, Clark M, et al.Are topoisomerase II inhibitorinduced micronuclei in vitro a predictive marker for the compounds' ability to cause secondary leukemias after treatment? Toxicol Lett. 1999;104(1-2):103-110.

57. Mulholland DA, Taylor DAH. A new limonoid from Aphanamixis polystachya. J Chem Res Synop. 1979. P . 294.

58. Jolad S, Hoffman J, Schram K, et al. Constituents of Trichilia hispida (Meliaceae). J Org Chem. 1981;46(3):641-644.

59. Brown DA, Taylor DAH. Limonoid extractives from Aphanamixis polystachya. Phytochem. 1978;17(11):1995-1999.

60. Gullo VP, Miura T, Nakanishi K, et al. Structure of Prieuranin, a complex tetranortriterpenoid. J Chem Soc Chem Commun. 1975.p. 345-346.

61. Connolly JD, Okorie, DA, et al.Structure of Dregeanin and Rohitukin. Chem Comm. 1976.p. 909

62. MacLachlan L, Taylor DAH. A revision of the structure of three limonoids. Phytochem. 1982;21(9):2426-2427.

63. The Wealth of India. Raw materials. Council of scientific and Industrial Research, New Delhi, India. 1964.p. 1919. 
64. Vickers A. Botanical medicines for the treatment of cancer: rationale, overview of current data, and methodological considerations for Phase I and II trials. Cancer Invest. 2002;20(7-8):1069-1079.

65. Williamson EM. Synergy and other interactions in phytomedicines. Phytomed. 2001;8(5):401-409.
66. World Health Organization. Traditional medicine strategy2002-2005. Geneva, Switzerland: World Health Organization; 2002. 